\title{
Clinical and biochemical outcome of patients with polycystic ovary syndrome managed with life style modification or combination with metformin
}

\author{
Nabi MU', Pathan $\mathbf{M F}^{\mathrm{b}}$, Barua $\mathbf{M}^{\mathrm{c}}$, Kabir $\mathbf{M M}^{\mathrm{d}}$, Alam $\mathbf{M J}^{\mathrm{e}}$, Jannut $\mathrm{KM}^{\mathrm{f}}$
}

\begin{abstract}
Background: Polycystic ovary syndrome (PCOS) is a common endocrine disorder with diverse reproductive and metabolic features. It is caused by insulin resistance that is exacerbated by obesity. Lifestyle modification is the first line treatment in PCOS, but it is associated with low adherence and sustainability. In small studies, metformin improves outcomes such as menstrual cycle problem, reduces the features of hyperandrogenism (hirsutism) and metabolic parameters (lipid profile). This study aimed to compare clinical and biochemical outcome of patients with polycystic ovary syndrome managed with life style modification or combination with metformin.

Methods: This prospective interventional study was carried out at Endocrine OPD, BIRDEM, from November 2016 to March 2018. Newly detected cases of PCOS were taken as study sample. Sampling technique was purposive and then randomly selected into two groups; Group $A(n=40)$ with lifestyle modification and Group B $(n=40)$ with lifestyle modification plus metformin (500mg TDS). The clinical [weight, body mass index (BMI), waist circumference, menstrual problem, hirsutism) and biochemical [serum testosterone, LH, FSH, fasting lipid profile] outcome of intervention with lifestyle modification and combination with metformin was studied.

Results: Baseline characteristics of both groups had no significant difference. After 12 months, there was significant improvement in hirsutism, menstrual problem and significant decrease in weight, BMI, waist circumference in both groups. Among hormonal profile there was significant reduction of testosterone in Group B $(p=0.01)$, whereas LH, FSH and LH: FSH ratio showed no significant difference. There was significant improvement of $H D L$ (in both groups) and reduction of triglyceride (TG) ( $p=0.005$, in group B). Outcome differences between two groups had shown significant improvement in weight, BMI, testosterone, HDL, TG level and on menstrual regulation. But there was no significant difference in waist and Ferriman-Gallwayscore in between groups.

Conclusion: lifestyle management is the first and most important step in the management of PCOS and addition of metformin to lifestyle modification appears to provide additional advantages. These results suggest the combination of lifestyle with metformin has a role to play in weight management: a key concern for women with PCOS. Addition of metformin also causes reduction of TG and testosterone, which is vital for PCOS management and found in this study.
\end{abstract}

Key words: polycystic ovary syndrome, life style modification, metformin, hirsutism.

(BIRDEM Med J 2020; 10(1): 26-33)

Author information

a. Md. Masud Un Nabi, MBBS, MD, Department of Endocrinology and Metabolism, BIRDEM General Hospital, Dhaka.

b. Md. Faruque Pathan MBBS, MD, Prof. and Head, Dept of Endocrinology and Metabolism, BIRDEM General Hospital, Dhaka.

c. Milton Barua, MBBS, MD, Department of Endocrinology and Metabolism, BIRDEM General Hospital, Dhaka, Bangladesh.

d. Md. Mahmudul Kabir, MBBS, MD, Department of Endocrinology and Metabolism, BIRDEM General Hospital, Dhaka.

e. Md. Jahangir Alam, MBBS, MD, Department of Endocrinology and Metabolism, BIRDEM General Hospital, Dhaka.

f. Khandker Mahbuba Jannut, MBBS, FCPS (Gynae and Obs), Medical Officer, 250 Bedded General hospital, Pabna.

Address of correspondence: Md. Masud Un Nabi, MBBS, MD, Department of Endocrinology and Metabolism, BIRDEM General Hospital, Dhaka, Bangladesh. Email: masudnabi@gmail.com

Received: May 23, 2019

Accepted: October 31, 2019

\section{Introduction}

Polycystic ovary syndrome (PCOS) is the most common endocrine disorder amongst women of reproductive age. PCOS is characterized by anovulatory menstrual cycle, infertility, hyperandrogenism and clinically manifested by irregular menstruation, hirsutism, obesity and acne thus resemble different metabolic syndromes. ${ }^{1}$ It is a heterogeneous disorder of uncertain etiology, but there is strong evidence that complex interactions between genetic, environmental and behavioral factors contribute in pathogenesis of this syndrome. ${ }^{2}$ Incidence of PCOS in women of reproductive age is reported to be 5 to $10 \%{ }^{3}$ The most widely used 1990 National Institutes of Health (NIH) criteria include clinical and/or biochemical 
hyperandrogenism and chronic anovulation. ${ }^{4}$ The 2004 Rotterdam criteria (Rotterdam ESHRE/ASRMSponsored PCOS Consensus Workshop Group) suggest PCOS should be diagnosed by two of the following three criteria: oligo-anovulation, clinical or biochemical hyperandrogenism and poly-cystic ovaries (PCOs) on ultrasound. Recent Androgen Excess and PCOS Society (AE-PCOS Society) criteria recommend that PCOS should be defined as clinical or biochemical hyperandrogenism associated with ovulatory dysfunction in the form of oligo-anovulation or PCO. Emerging data suggest obesity and PCOS has a bidirectional relationship. The more a person is obese the more chance of developing PCOS. ${ }^{6}$ Consistently, weight loss through lifestyle modification (comprising dietary modification, physical activity and/or behavioral change), medications (metformin, orlistat, incretinmimetics) or bariatric surgery improves insulin resistance, reduces hyperandrogenism and reduces PCOS clinical severity. ${ }^{7}$ Lifestyle management (LSM) is first line therapy in PCOS for prevention of weight gain. ${ }^{8}$ Metformin increases insulin sensitivity by decreasing gluconeogenesis, lipogenesis and enhancing glucose uptake in the liver, skeletal muscle, adipose tissue and ovaries. In PCOS, metformin reduces insulin resistance and inhibits ovarian androgen production via its effects on steroidogenic acute regulatory protein and 17 alphahydroxylase.Based on current guidelines, metformin is indicated in PCOS in some scenarios to improve fertility ${ }^{6}$, for management of menstrual irregularity if women are unable to take OCPs and in co-existent prediabetes or diabetes, where lifestyle modification fails. ${ }^{9}$ Previous observational studies showed that LSM can be associated with clinical improvement in PCOS. Moderate weight loss during long term calorie restriction is associated with marked clinical improvement in menstrual function and fertility. ${ }^{10}$ In a retrospective study, weight loss is associated with improvement in ovulation, pregnancy outcome, self-esteem, and endocrine parameters in women who are infertile and overweight.In brief, changes in diet and lifestyle remain the primary choice in the management of reproductive and metabolic and cardiovascular (CV)sequelae in overweight and obese women with PCOS. Metformin is the primary insulin sensitizing drug to be used as an adjuvant to general lifestyle modification in patients who have impaired glucose tolerance (IGT) or overt type 2 diabetes. Furthermore, accumulating evidence shows that, in a subset of women with PCOS, metformin treatment may be effective for the improvement of reproductive function irrespective of insulin resistance and glucose intolerance. ${ }^{11}$ This study was designed to compare clinical and biochemical outcome of patients with polycystic ovary syndrome managed with life style modification or combination with metformin.

\section{Methods}

This prospective interventional study conducted in the BIRDEM General Hospital 1 and 2 in Endocrine OPD from November 2016 to March 2018. The women of reproductive age (15-40 Years) either married or unmarried already diagnosed as polycystic ovary syndrome without any intervention considered as study population. Subject selection was done as per inclusion and exclusion criteria. After full explanation of the study procedure informed written consent was taken. A detailed history was obtained. Data wwere collected in a structured questionnaire. After enrollment in the study, the study subjects were randomly divided into two groups. Group A gone through life style modification and Group B had combination of life style modification and metformin. Anthropometric measurements including height in $\mathrm{cm}$, weight in $\mathrm{kg}$ and waist circumference (WC) in cm was. The BMI was calculated by dividing the weight (in $\mathrm{kg}$ ) by the height (in $\mathrm{m}$ ) squared to assess obesity. Each patientwas counseled about drug side effect. They were sent to nutritionist to formulate a weight reducing diet plan and advised to walk at least 1 hour per day. The amount of terminal hair growth assessed using a modified FerrimanGallwaymethod in which the upper lip, chin, chest, upper and lower abdomen, thighs, upper and lower back and upper arms were scored from 0 to 4 .Subjects (Group A and Group B) were asked to follow up after 12 months with the hormonal (S.testosterone, LH, FSH), biochemical (fasting lipid profile) report. At that time clinical examination and anthropometric measurement was also done.Study subjects were made contact frequently over phone to inquiry about compliance and any drug related side effect. If any side effect occurred then it was noted down and if not severe, subjects were counseled to continue the medication.After editing and coding, the coded data were directly entered into the computer by using SPSS software, version 22.0. Data cleaning validation and analysis were performed using the SPSS software. Categorical data were presented as percentage and continuous variable were expressed as mean $\pm \mathrm{SD}$ (standard deviation). An independent sample Student's t-test was used for comparison of means of continuous variables with normal or approximately normal distributions. The Chi-square test was used to analyze discrete variables. Confidence interval was set at $95 \%$ level. Statistical significance was set at $\mathrm{p}<0.05$. 


\section{Results}

Total 80 patients were taken and divided in two groups equally. Baseline characteristics of the two groups shown in Table Iand IIand found no difference in two groups.

In Group A (LSM only), there are significant decrease in weight (mean change: -1.6 , p-value $<0.01$ ), BMI (mean change:-0.54, p-value $<0.001$ ) waist circumference (mean change: -4.6 , p-value $<0.002$ ) and improvement of hirsutism total score in the study subject (mean change:-3.6, p-value $<0.01$ ) at the end of the study. In Group B (LSM plus metformin), there are significant decrease in weight (mean change: $-4.33, \mathrm{p}$ value $<0.0001$ ), BMI (mean change:-4.0, p value $<0.001$ ), waist circumference (mean change: -7.1 , pvalue: 0.006 ) and improvement of hirsutism total score in the study subject (mean change:-5.2, p-value: 0.004 ) at the end of the study as shown in Table III.

At the end of study period, there was significant decrease in testosterone level found in Group B (mean change: 1.7, p-value: 0.01 ) as shown in table 4 . There is no effect on FSH and LH level and ratio after the end of the study period in two groups (Table IV).

Table I Baseline characteristic (clinical, anthropometric, hormonal and lipid profile) of the patients

\begin{tabular}{|c|c|c|c|}
\hline $\begin{array}{l}\text { Baseline characteristic } \\
\text { Anthropometric and } \\
\text { Clinical }\end{array}$ & $\begin{array}{c}\text { Group A } \\
\begin{array}{c}\text { Patients with life style } \\
\text { modification }(\mathrm{n}=40)\end{array} \\
\end{array}$ & $\begin{array}{c}\text { Group B } \\
\text { Patients with lifestyle and } \\
\text { Metformin therapy }(\mathrm{n}=40)\end{array}$ & $\begin{array}{l}\text { Difference in } \\
\text { between group }\end{array}$ \\
\hline \multirow[t]{2}{*}{ Age (yr) } & $29.1 \pm 4.3$ & $30.4 \pm 5.4$ & 0.237 \\
\hline & $(18-32)$ & $(19-36)$ & Ns \\
\hline \multirow[t]{2}{*}{ Weight (kg) } & $81.56 \pm 2.95$ & $82.0 \pm 5.2$ & 0.643 \\
\hline & $(58-110)$ & $(54-112)$ & Ns \\
\hline \multirow[t]{2}{*}{ BMI (kg/m2) } & $31.99 \pm 0.79$ & $31.7 \pm 4.5$ & 0.689 \\
\hline & $(24-38)$ & $(23-37)$ & Ns \\
\hline \multirow[t]{2}{*}{ Waist (cm) } & $110.4 \pm 8.5$ & $112.9 \pm 13.6$ & 0.327 \\
\hline & $(82-125)$ & 84-119 & Ns \\
\hline Ferriman-Gallwey & $17.7 \pm 6.2$ & $19.1 \pm 8.9$ & 0.417 \\
\hline score & $(10-26)$ & $(12-24)$ & Ns \\
\hline \multicolumn{4}{|l|}{ Hormones } \\
\hline \multirow[t]{2}{*}{ Testosterone (ng/ml) } & $0.68 \pm 0.15$ & $0.63 \pm 0.17$ & 0.167 \\
\hline & $(0.45-1.10)$ & $(0.34-1.23)$ & Ns \\
\hline \multirow[t]{2}{*}{ FSH(mIU/mL) } & $5.0 \pm 1.9$ & $4.8 \pm 2.3$ & 0.673 \\
\hline & $(4-8)$ & $(5-9)$ & Ns \\
\hline \multirow[t]{2}{*}{$\mathrm{LH}(\mathrm{mIU} / \mathrm{mL})$} & $8.7 \pm 4.0$ & $8.5 \pm 2.0$ & 0.778 \\
\hline & $(07-19)$ & $(06-17)$ & Ns \\
\hline \multirow[t]{2}{*}{ LH/FSH ratio } & 1.74 & 1.98 & 0.737 \\
\hline & $(0.4-2.65)$ & $(0.35-2.72)$ & Ns \\
\hline \multicolumn{4}{|l|}{ Lipid parameters } \\
\hline \multirow[t]{2}{*}{ Cholesterol (mg/dL) } & $187.4 \pm 55.4$ & $186.0 \pm 52.6$ & 0.908 \\
\hline & $(78-320)$ & $(65-345)$ & Ns \\
\hline \multirow[t]{2}{*}{ HDL (mg/dL) } & $37.1 \pm 15.8$ & $36.7 \pm 13.2$ & 0.903 \\
\hline & $(28-65)$ & $(28-54)$ & Ns \\
\hline LDL (mg/dL) & $123.9 \pm 45.7(75-199)$ & $121.8 \pm 42.2(72-230)$ & $0.831 \mathrm{Ns}$ \\
\hline \multirow[t]{2}{*}{ Triglycerides (mg/dL) } & $128.5 \pm 87.4$ & $125.8 \pm 88.1$ & 0.891 \\
\hline & $(76-489)$ & $(74-565)$ & $\mathrm{Ns}$ \\
\hline
\end{tabular}

$\mathrm{Ns}=$ Not Significant (independent $\mathrm{t}$ test was done) 
Table II Menstrual history of the PCOS patients at the baseline in between two groups

\begin{tabular}{lccc}
\hline Menstrual characteristics & $\begin{array}{c}\text { Group A } \\
\text { Patients with life } \\
\text { style modification } \\
(\mathrm{n}=40)\end{array}$ & $\begin{array}{c}\text { Group B } \\
\text { Patients with lifestyle and } \\
\text { Metformin therapy } \\
(\mathrm{n}=40)\end{array}$ & $\begin{array}{c}\text { Difference in } \\
\text { between group }\end{array}$ \\
\hline Menstrual duration & $5.0 \pm 0.57$ & $4.8 \pm 1.5$ & $0.53(\mathrm{t}$ test) \\
Mean days \pm SD & $(02-17)$ & $(03-21)$ & Ns \\
Number of menstrual & $5.46 \pm 0.84$ & $5.48 \pm 0.53$ & 0.89 (t test) \\
cycles in last year. Mean days \pm SD & $(02-08)$ & $(03-07)$ & NS \\
Amenorrhoea & 11 & 14 & 0.58 (Chi square) NS \\
Oligomenorrhoea & 29 & 26 & 0.61 (Chi square) NS \\
\hline
\end{tabular}

Table III Anthropometric effects after intervention in group A \& group B

\begin{tabular}{|c|c|c|c|c|c|c|c|c|}
\hline \multirow[t]{2}{*}{ Variable } & \multicolumn{3}{|c|}{ Patients with life style modification (Group A) } & \multicolumn{5}{|c|}{ Patients with lifestyle and Metformin (Group B) } \\
\hline & $\begin{array}{c}\text { Baseline } \\
\mathrm{n}=40\end{array}$ & $\begin{array}{c}\text { 12th month } \\
\mathrm{n}=32\end{array}$ & $\begin{array}{c}\text { Mean change } \\
(95 \% \mathrm{CI})\end{array}$ & $\mathrm{P}$ value & $\begin{array}{c}\text { Baseline } \\
\mathrm{n}=40\end{array}$ & $\begin{array}{c}\text { 12th month } \\
n=33\end{array}$ & $\begin{array}{l}\text { Mean change } \\
(95 \% \mathrm{CI})\end{array}$ & $\begin{array}{c}\mathrm{P} \\
\text { Value }\end{array}$ \\
\hline \multirow[t]{3}{*}{ Weight (kg) } & 81.56 & $79.96 \pm$ & -1.6 & 0.01 & 82 & 77.67 & -4.33 & $<0.0001$ \\
\hline & \pm 2.95 & 2.65 & $(-2.8$ to -0.35$)$ & & \pm 5.2 & \pm 3.3 & $(-6.26$ to -2.39$)$ & \\
\hline & $(80.61-82.50)$ & $(79.00-80.91)$ & & & $(80.33-83.66$ & (76.49-78.84 & & \\
\hline BMI $\left(\mathrm{kg} / \mathrm{m}^{2}\right)$ & $\begin{array}{c}31.99 \pm 0.79 \\
(31.73- \\
32.24)\end{array}$ & $\begin{array}{c}31.45 \pm 0.65 \\
(31.21- \\
31.68)\end{array}$ & $\begin{array}{l}-0.54(-0.86 \\
\text { to }-0.21)\end{array}$ & 0.001 & $\begin{array}{c}31.7 \pm 1.2 \\
(31.31- \\
32.08)\end{array}$ & $\begin{array}{c}27.7 \pm 3.88 \\
(26.32- \\
29.07)\end{array}$ & $\begin{array}{c}-4.0(-5.27 \\
\text { to }-2.72)\end{array}$ & $<0.0001$ \\
\hline $\begin{array}{l}\text { Waist } \\
\text { circumference (cn }\end{array}$ & $\begin{array}{c}110.4 \\
\pm 8.5 \\
(107.68- \\
113.11)\end{array}$ & $\begin{array}{c}105.8 \pm \\
3.67 \\
(104.47 \\
-107.12)\end{array}$ & $\begin{array}{c}-4.6 \\
(-7.51 \text { to }- \\
1.68)\end{array}$ & 0.002 & $\begin{array}{c}112.9 \\
\pm 13.6 \\
(111.75- \\
114.06)\end{array}$ & $\begin{array}{c}105.78 \\
\pm 8.32 \\
(102.82- \\
108.73)\end{array}$ & $\begin{array}{c}-7.1 \\
(-12.13 \text { to }- \\
2.10)\end{array}$ & 0.006 \\
\hline $\begin{array}{l}\text { Ferriman-Gallwey } \\
\text { score }\end{array}$ & 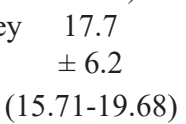 & $\begin{array}{c}14.01 \pm \\
6.4 \\
(11.70-16.31)\end{array}$ & $\begin{array}{c}-3.6 \\
(-6.49 \text { to }-0.88)\end{array}$ & 0.010 & $\begin{array}{c}19.1 \\
\pm 8.9 \\
(16.25-21.94\end{array}$ & $\begin{array}{c}13.87 \\
\pm 6.76 \\
(10.47-15.26\end{array}$ & $\begin{array}{l}-5.2 \\
(8.74 \text { to-1.71) } \\
\text { 6) }\end{array}$ & 0.004 \\
\hline
\end{tabular}

Note: Paired t test was done.

Table IV Hormonal effects after intervention in group A \& group B

\begin{tabular}{|c|c|c|c|c|c|c|c|c|}
\hline \multirow[t]{2}{*}{ Variable } & \multicolumn{3}{|c|}{$\begin{array}{l}\text { Patients with life style modification } \\
\text { (Group A) }\end{array}$} & \multirow[b]{2}{*}{$\begin{array}{c}\mathrm{P} \\
\text { value }\end{array}$} & \multicolumn{4}{|c|}{$\begin{array}{l}\text { Patients with lifestyle and Metformin } \\
\text { (Group B) }\end{array}$} \\
\hline & $\begin{array}{l}\text { Baseline } \\
\mathrm{n}=40\end{array}$ & $\begin{array}{c}12 \text { th } \\
\text { month } \\
n=32\end{array}$ & $\begin{array}{c}\text { Mean } \\
\text { change } \\
(95 \% \mathrm{CI})\end{array}$ & & $\begin{array}{l}\text { Baseline } \\
n=40\end{array}$ & $\begin{array}{c}12 \text { th } \\
\text { month } \\
n=33\end{array}$ & $\begin{array}{c}\text { Mean } \\
\text { change } \\
(95 \% \mathrm{CI})\end{array}$ & $\begin{array}{c}\mathrm{P} \\
\text { value }\end{array}$ \\
\hline Testosteroe & 7.3 & 7.2 & -0.1 & 0.9 & 7.5 & 5.8 & -1.7 & 0.01 \\
\hline (ng/mL) & $\begin{array}{c} \pm 3.6 \\
(6.1-8.4)\end{array}$ & $\begin{array}{c} \pm 3.5 \\
(5.9-8.4)\end{array}$ & $\begin{array}{l}(-1.5 \text { to } 1.7) \\
(6.4-8.5)\end{array}$ & $(5.0-6.5)$ & \pm 3.4 & \pm 2.0 & $(0.3-3.0)$ & \\
\hline $\begin{array}{l}\text { FSH } \\
(\mathrm{mIU} / \mathrm{mL})\end{array}$ & $\begin{array}{c}5.0 \\
\pm 1.9 \\
(4.39-5.60)\end{array}$ & $\begin{array}{c}4.84 \\
\pm 1.28 \\
(4.37-5.30)\end{array}$ & $\begin{array}{c}-0.16 \\
(-0.88 \text { to } 0.56)\end{array}$ & 0.659 & $\begin{array}{c}4.8 \\
\pm 2.3 \\
(4.06-5.53)\end{array}$ & $\begin{array}{c}5.3 \\
\pm 2.89 \\
(4.27-6.32)\end{array}$ & $\begin{array}{c}0.50 \\
(-0.66 \text { to } 1.6)\end{array}$ & 0.39 \\
\hline LH (mIU/mL) & $\begin{array}{c}8.7 \\
\pm 4.0 \\
(7.4-9.9)\end{array}$ & $\begin{array}{c}7.37 \\
\pm 3.87 \\
(5.9-8.7)\end{array}$ & $\begin{array}{c}-1.33 \\
(-3.08 \text { to } \\
0.42)\end{array}$ & 0.134 & $\begin{array}{c}8.5 \\
\pm 2.0 \\
(7.8-9.1)\end{array}$ & $\begin{array}{c}7.83 \\
\pm 1.78 \\
(7.19-8.46)\end{array}$ & $\begin{array}{c}-0.67 \\
(-1.51 \text { to } \\
0.17)\end{array}$ & 0.11 \\
\hline $\begin{array}{l}\text { LH: FSH } \\
\text { Ratio }\end{array}$ & 1.74 & 1.52 & $\begin{array}{c}-0.12 \\
(-0.06 \text { to } 1.08)\end{array}$ & 0.087 & 2.18 & 1.85 & $\begin{array}{c}-0.33 \\
-0.17 \text { to } 2.03)\end{array}$ & 0.076 \\
\hline
\end{tabular}

Note: Paired t test was done. 
At the end of the study period, table 5 shows a significant improvement in HDL level in Group A (mean change: 6.8, p-value: 0.04) \& more significant improvement in group B (mean change: 10.6, p-value: 0.001). There is no effect on LDL and Total Cholesterol level after the end of the study period in two groups. There is a significant decrease in TG level (mean change: 43.4, pvalue: 0.005$)$ in lifestyle and metformin intervention group (Table V).
At the end of the study, $22(55 \%)$ and $30(75 \%)$ women from Group A and B were menstruating regularly compared to none at baseline. In group A, amenorrhea $11(27.5 \%)$ and oligomenorrhoea 29(72.5\%), was significantly improved by 6 (15\%) \& $16(40 \%)$ respectively. In group B, amenorrhea 14 (35\%) and oligomenorrhoea 26 (65\%), was significantly improved by $03(7.5 \%) \& 07(17.5 \%)$ respectively as shown in Table VI.

Table $\mathbf{V}$ Lipid profile change after intervention between two groups.

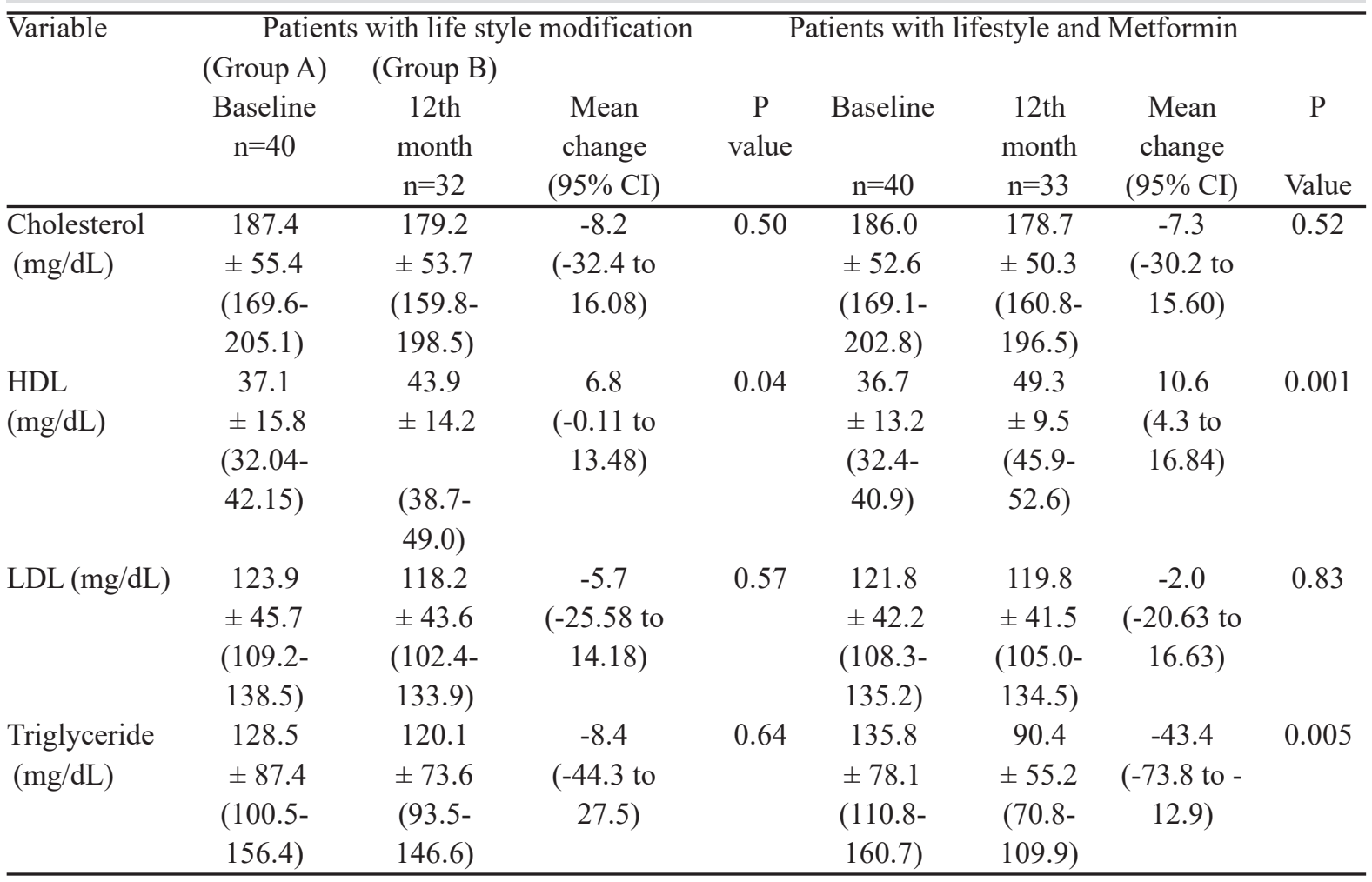

Note: Paired t test was done.

Table VI Menstrual effects after intervention in between two groups

\begin{tabular}{lcccccc}
\hline Variable & $\begin{array}{c}\text { Patients with life style modification (Group A) } \\
\text { Baseline }\end{array}$ & $\begin{array}{c}\text { 12th } \\
\text { P value }\end{array}$ & Patients with lifestyle and Metformin therapy (Group B) \\
& $(\mathrm{n}=40)$ & month $(\mathrm{n}=32)$ & & $\begin{array}{c}\text { Baseline } \\
(\mathrm{n}=40)\end{array}$ & 12th & month $(\mathrm{n}=33)$ \\
\hline Amenorrhea & 11 & 06 & 0.01 & 14 & 03 & 0.001 \\
Oligomenorrhoea & 29 & 16 & 0.01 & 26 & 07 & 0.001 \\
Regular & 0 & 18 & 0.001 & 0 & 30 & 0.001 \\
menstruation & & & & & & \\
\hline
\end{tabular}

Note: chi-square test was done 
Outcome difference about clinical parameters after completion of the study Hirsutism mean score was improved ( $\mathrm{p}$-value is $<0.08$ ) and menstrual regularity was more improved ( $p$-value $<0.01$ ) in lifestyle with Metformin intervention group than with lifestyle intervention alone.BMI (p-value 0,001) and Weight (p-value 0.0001) was significantly reduced in lifestyle with Metformin intervention group than lifestyle alone intervention group. There is no outcome difference in waist circumference ( $p$-value 0.99 ) in between two intervention group. There is improved HDL level (pvalue 0.05 ) and significant decreased in TG level (pvalue 0.04 ) in life style intervention with Metformin group than lifestyle intervention alone group. There is no outcome difference in serum cholesterol and LDL level in between two intervention group. There is significant outcome difference in testosterone ( $p$-value 0.03 ) in lifestyle plus Metformin intervention group than lifestyle intervention alone group. There is no outcome difference in $\mathrm{FSH}, \mathrm{LH}$ and $\mathrm{FSH} / \mathrm{LH}$ ratio.All of these shown in Table VII. In group A $80 \%$ compliance and Group B 82.5\% compliance rate. Drug induce adverse effect in lifestyle plus Metformin group was about $20 \%$ people complained abdominal discomfort, $7.5 \%$ diarrhoea, $12.5 \%$ nausea and vomiting $5 \%$.

Table VII Outcome difference of all parameters after completion of the study in between two intervention groups

\begin{tabular}{|c|c|c|c|}
\hline $\begin{array}{l}\text { Variable } \\
\text { (Clinical) }\end{array}$ & $\begin{array}{c}\text { Lifestyle } \\
\text { modification (Group } \\
\text { A n=32) } \\
\text { (Mean Change) }\end{array}$ & $\begin{array}{c}\text { Lifestyle }+ \\
\text { Metformin } \\
\text { (Group B n=33) } \\
\text { (Mean Change) }\end{array}$ & $P$ value \\
\hline Ferriman-Gallwey score & $\begin{array}{c}-3.6 \\
(-6.49 \text { to }-0.88)\end{array}$ & $\begin{array}{c}-5.2 \\
(8.74 \text { to }-1.71)\end{array}$ & .08 \\
\hline Menstruation & & & \\
\hline Regular & 22 & 30 & 0.01 \\
\hline Weight (kg) & $\begin{array}{c}-1.6 \\
(-2.8 \text { to }-0.35)\end{array}$ & $\begin{array}{c}-4.33 \\
(-6.26 \text { to }-2.39)\end{array}$ & 0.001 \\
\hline BMI (kg/m2) & $\begin{array}{c}-0.54 \\
(-0.86 \text { to }-0.21)\end{array}$ & $\begin{array}{c}-4.0 \\
(-5.27 \text { to }-2.72)\end{array}$ & 0.0001 \\
\hline $\begin{array}{l}\text { Waist circumference } \\
(\mathrm{cm})\end{array}$ & $\begin{array}{c}-4.6 \\
(-7.51 \text { to }-1.68)\end{array}$ & $\begin{array}{c}-7.1 \\
(-12.13 \text { to }-2.10)\end{array}$ & 0.99 \\
\hline $\begin{array}{l}\text { Total Chol } \\
(\mathrm{mg} / \mathrm{dl})\end{array}$ & $\begin{array}{c}-8.2 \\
(-32.4 \text { to } 16.08)\end{array}$ & $\begin{array}{c}-7.3 \\
(-30.2 \text { to } 15.60)\end{array}$ & 0.57 \\
\hline $\begin{array}{l}\mathrm{HDL} \\
(\mathrm{mg} / \mathrm{dl})\end{array}$ & $\begin{array}{c}6.8 \\
(-0.11 \text { to } 13.48)\end{array}$ & $\begin{array}{c}10.6 \\
(4.3 \text { to } 16.84)\end{array}$ & 0.05 \\
\hline $\begin{array}{l}\mathrm{LDL} \\
(\mathrm{mg} / \mathrm{dl})\end{array}$ & $\begin{array}{c}-5.7 \\
(-25.58 \text { to } 14.18)\end{array}$ & $\begin{array}{c}-2.0 \\
(-20.63 \text { to } 16.63)\end{array}$ & 0.85 \\
\hline Triglycerides (mg/dl) & $\begin{array}{c}-8.4 \\
(-44.3 \text { to } 27.5)\end{array}$ & $\begin{array}{c}-43.4 \\
(-73.8 \text { to }-12.9)\end{array}$ & 0.04 \\
\hline Testosterone (ng/mL) & $\begin{array}{c}-0.1 \\
(-1.5 \text { to } 1.7)\end{array}$ & $\begin{array}{c}-1.7 \\
(0.3-3.0)\end{array}$ & 0.03 \\
\hline S.LH (mIU/ml) & $\begin{array}{c}-1.33 \\
(-3.08 \text { to } 0.42)\end{array}$ & $\begin{array}{c}-0.67 \\
(-1.51 \text { to } 0.17)\end{array}$ & 0.87 \\
\hline S.FSH (mIU/ml) & $\begin{array}{c}-0.16 \\
(-0.88 \text { to } 0.56)\end{array}$ & $\begin{array}{c}0.50 \\
(-0.66 \text { to } 1.6)\end{array}$ & 0.26 \\
\hline LH: FSH Ratio & $\begin{array}{c}-0.12 \\
(-0.06 \text { to } 1.08)\end{array}$ & $\begin{array}{c}-0.33 \\
(-0.17 \text { to } 2.03)\end{array}$ & 0.96 \\
\hline
\end{tabular}

Note: independent $\mathrm{t}$ test done 


\section{Discussion}

PCOS is one of the most common endocrine disorders in woman of reproductive age. This is a prospective interventional study to investigate the effects of lifestyle alone or combination with Metformin on patients with PCOS. Total 80 patients were enrolled in this study and then randomly divided into group A (Subjects with lifestyle modification) and Group B (Subjects with lifestyle modification plus Metformin). Both groups were follow-up after 12 months and the dose of Metformin used $500 \mathrm{mg}$ three times daily. There is no significant difference in baseline characteristics in between two groups. In study done by Barbieri ${ }^{12}$ showed that, there was no significant difference among baseline characteristics (clinical, anthropometric, hormonal and lipid profile) in between groups. After 12 months of therapy, group A had $80 \%$ compliance. Whereas group $\mathrm{B}$ had $82.5 \%$ compliance. In Group $\mathrm{A}$ at the end of the study period, there is significant decrease in weight, BMI, waist circumference, and Hirsutism total score was significantly improved. Study done by Bruner et $\mathrm{al}^{13}$ showed similar results in their study after lifestyle intervention in PCOS obese patients. Lifestyle modification induced weight loss improves all metabolic parameters and also hyperandrogenism. ${ }^{10,11}$ This was supported by Brunner ${ }^{13}$, who mentioned weight reduction has shown to alleviate Hirsutism and acne. Linderbaum ${ }^{14}$ reported similar improvement of acne and Hirsutism after lifestyle modification. Study done byHoeger ${ }^{5}$, didn't find significant changes of Hirsutism scores by lifestyle. At the end of the study period in group B, there is significant decrease in weight, BMI, waist circumference, and Hirsutism total score was significantly improved. Barbieri ${ }^{12}$ showed that similar significant reduction in waist circumference and BMI in obese PCOS women after lifestyle plus Metformin intervention. Lord et al. 2003 showed that, the effect of Metformin on PCOS features could not confirm any weight-reducing effect. Menstrual dysfunction was significantly improved in both groups in this study. Similar study was done by Moran et. al. 2003 \& Foster et. al. 2003 who reported that weight loss alone through lifestyle changes improves menstrual frequency \& ovulation. Moghetiet. $\mathrm{al}^{17}$ showed that after Metformin treatment, mean frequency of menstruation improved in about $50 \%$ of subjects. Metformin therapy appears beneficial for improvement of menstrual cycle, ovulation and hyperandrogenism in some women. These findings agreed with Lord.et.al (2003) who showed that Metformin is effective in achieving ovulation in PCOS. We found that the addition of Metformin to lifestyle had significant benefit on circulating androgen level. In this study testosterone level was significantly decreased in metformin treated group but not in LSM group. There is also no effect on FSH, LH level and LH: FSH ratio after the end of the study period in both groups. This observation agreed that, Metformin may have a direct effect on ovarian steroid-genesis. ${ }^{18}$ Another study showed that Metformin was effective in reducing total testosterone concentrations but had no effect on BMI or waist circumference. ${ }^{19}$ Similar result found in a double-blind placebo-controlled RCT of nine months revealed that metformin has significant beneficial effect on androgenous activity of PCOS. ${ }^{20}$ Study done by Nahar etal showed that there are significant relationship between irregular menstrual cycle pattern and hormonal changes such as testosterone level. ${ }^{21}$ Our study also supported by other studies ${ }^{11,17}$; who reported that, a fall in BMI showed an improvement in menstrual cycle; so as a fall in testosterone concentrations. There is more significant increase in HDL level in Group B then Group A and significantly decrease in TG level in group B. Metformin significantly decreased body fat and also raised circulating high-density lipoprotein cholesterol. PCOS patients treated with Metformin had a significant reduction in total cholesterol, LDL cholesterol and TG levels and an increase in HDL cholesterol levels ${ }^{17,22}$. Metformin inhibits ovarian steriodogenesis, increase lipolysis, decreases insulin resistance and decrease hepatic glucose output. For this reason the combination group may have shown more significant outcome.

\section{Conclusion}

The effects of lifestyle modification or combination with Metformin both are generally beneficial; the absolute changes are quite modest. This study shows that adding Metformin with LSM brings out improvement in clinical (wt, BMI, waist circumference, menstrual problem and Hirsutism score) and biochemical (S.Testosterone and triglyceride level). LSM is the core component of PCOS management. In conclusion lifestyle management is the first and most important step in the management of PCOS, addition of Metformin to lifestyle modification appears to provide additional advantages.

Conflict of interest: Nothing to declare. 


\section{References}

1. Hahn S, Quadbeck B, Elsenbruch S, Gartner R, Finke R, Mann K.Metformin an efficacious drug in the treatment of polycystic ovary syndrome. Dtsch Med Wochenschar 2004; 129: 1059-1064.

2. Bargiota A and Diamanti-Kandarakis E. The effect of old, new and emerging medicines on metabolic aberrations in PCOS. Therapeutic Advances in Endocrinology and Metabolism2012; 3(1): 27-47.

3. Fleming R, Hopkinson ZE, Wallace AM, Greer IA, Sattar N. Ovarian function and metabolic factors in women with oligomenorrhea treated with metformin in a randomized double blind placebo-controlled trial. J. Clin. Endocrinol. Metab 2002; 87(2): 569-574.

4. Zawadski JK, Dunaif A. Diagnostic criteria for polycystic ovary syndrome: towards a rational approach. In: Dunaif A, Givens JR, Haseltine FP, Merriam GR. Polycystic Ovary Syndrome. Boston: Blackwell Scientific Publications 1992: 377-384.

5. Azziz R, Marin C, Hoq L et al. Health care-related economic burden of the polycystic ovary syndrome during the reproductive life span. J ClinEndocrinolMetab 2005;90: 4650-8.

6. Teede HJ, Misso ML, Deeks AA, Moran LJ, Stuckey BG, Wong JL, Norman RJ, Costello MF; Guideline Development Groups. Assessment and management of polycystic ovary syndrome: summary of an evidence-based guideline. Med J Aust2011 Sep 19;195(6): 65-112.

7. Moran LJ, Noakes M, Clifton PM, Tomlinson L, Norman RJ. Dietary composition in restoring reproductive and metabolic physiology in overweight women with polycystic ovary syndrome. J ClinEndocrinolMetab2003; 88:812-819.

8. Teede HJ, Anju E, Paul JE, Lisa J. Moran LJ, Loxton D, Jolley D, Lombard C. Longitudinal Weight Gain in Women Identified With Polycystic Ovary Syndrome: Results of an Observational Study in Young Women. Obesity 2013; 21: 1526-1532.

9. Legro RS, Driscoll D, Strauss JF, Fox J, Dunaif A. Evidence for a genetic basis for hyperandrogenemia in polycystic ovary syndrome. ProcNatlAcadSci USA; 1998; 95: 14956-14960.

10. Kumarapeli V, Seneviratne RA, Wijeyaratne CN, Yapa RM, Dodampahala SH. A simple screening approach for assessing community prevalence and phenotype of polycystic ovary syndrome in a semi-urban population in Sri Lanka. Am J Epidemiol2008;168:321-328.

11. Pasquali R, Casimirri F,Vicennati V.Weight control and its beneficial effect on fertility in women with obesity and polycystic ovary syndrome. Hum Reprod 12 1997;Suppl 1: 82-87.

12. BarbieriRL.Metformin for the treatment of polycystic ovary syndrome. ObstetGynecol 2003; 101: 785-793.

13. Bruner B, Chad K, Chizen D. Effects of exercise and nutritional counseling in women with polycystic ovary syndrome. ApplPhysiolNutrMetab2006 Aug;31(4):384-91.

14. Legro RS, Driscoll D, Strauss JF, Fox J, Dunaif A. Evidence for a genetic basis for hyperandrogenemia in polycystic ovary syndrome. ProcNatlAcadSci USA; 1998; 95: 14956-14960.

15. Hoeger K, Davidson K, Kochman L, Cherry T, Kopin L, Guzick DS. The Impact of Metformin, Oral Contraceptives, and Lifestyle Modification on Polycystic Ovary Syndrome in Obese Adolescent Women in Two Randomized PlaceboControlled Clinical Trials. The Journal of Clinical Endocrinology and Metabolism 2008;93(11):4299-4306.

16. Gambineri A, Pasquali R. Role of changes in dietary habits in polycystic ovary syndrome. Reproductive BioMedicine 2004;8: 431-439.

17. Moghetti P, Castello R, NegriC, Tosi F, Perrone F, Caputo M et al. Metformin effects on clinical features, endocrine and metabolic profiles, and insulin sensitivity in polycystic ovary syndrome: a randomized, double-blind, placebo-controlled 6month trial, followed by open, long-term clinical evaluation. J. Clin. Endocrinol. Metab 2000; 85(1): 139-146.

18. Pirwany, I.R. Yates, R.W. Cameron, I.T., Fleming, R. Effects of the insulin sensitizing drug metformin on ovarian function, follicular growth and ovulation rate in obese women with oligomenorrhoea. Human Reproduction1999; 14:2963-2968.

19. Lord JM, Flight IH, Norman RJ. Metformin in polycystic ovary syndrome: systematic review and meta-analysis. BMJ2003 Oct 25; 327(7421):951-3.

20. Akhter N, Hasnat MA, Banu H, Tuqan S, Mustari M, Sultana T, Fariduddin M. Effect of Metformin Therapy over Hormone Profiles in Newly Diagnosed Polycystic Ovary Syndrome- A Nine Months Randomized Controlled Trial. ARJE; 2016; V 1:1-9.

21. Nahar, K, Yasmin H, Pramanik, L. Study of Polycystic Ovaries in Mymensingh Medical College Hospital, Bangladesh. Journal of Bangladesh College of Physicians \& Surgeons; 2014 Jul; 32(3): 142-148.

22. Santana LF, de Sá MFS, Ferriani RA, de Moura MD, Foss MC, dos Reis RM. Effect of metformin on the clinical and metabolic assessment of women with polycystic ovary syndrome. Gynecol. Endocrinol; 2004; 19(2): 88-96. 